\title{
Fusarium spp from potato: polymorphism of esterase phenotypes on polyacrylamide gel electrophoresis
}

\author{
A Somé, B Tivoli \\ INRA, Station de Phytopathologie, Centre de Recherches de Rennes, BP 29, F35650 Le Rheu, France
}

(Received 29 June 1992; accepted 26 April 1993)

\begin{abstract}
Summary - Polyacrylamide gel electrophoresis was used to analyze 49 single-spore cultures of Fusarium from potatoes growing in the Brittany region of France. The isolates belonged to 3 species ( $F$ oxysporum, $F$ solani, and $F$ roseum), 5 varieties of $F$ roseum (sambucinum, arthrosporioides, culmorum, graminearum and gibbosum). Esterase patterns from the mycelium made it possible to unambiguously distinguish each species or variety. Depending on the species or varieties 6 to 20 isozymes were found, but only 3 or 4 of these could be used for identification. $F$ oxysporum, $F$ solani var coeruleum, and $F$ roseum var arthrosporioides showed highly distinctive enzyme patterns, while the esterase patterns of $F$ roseum var culmorum and var graminearum were closely related. Where morphological heterogeneity appeared between isolates of the same species or variety, the enzyme patterns were variable, such as in $F$ roseum var graminearum with 2 stet morphological sub-types and in $F$ roseum var arthrosporioides with its morphological variants. Based on these stable and fluctuating isozymes, we consider that $F$ roseum var arthrosporioides and $F$ roseum var avenaceum could be one and the same species. Lastly, the relation between tolerance to thiabendazole and esterase patterns of $F$ roseum var sambucinum is discussed.
\end{abstract}

electrophoresis / isozymes / systematics / morphology

Résumé - Polymorphisme des isoenzymes d'estérases d'espèces ou de variétés de Fusarium isolées de tubercules de pomme de terre. L'électrophorèse sur gel de polyacrylamide est utilisée pour analyser 49 isolats monospores de Fusarium issus pour la plupart de pomme de terre en Bretagne. Ces isolats appartiennent à 3 espèces ( $F$ oxysporum, $F$ solani et $F$ roseum), et 5 variétés de $F$ roseum (sambucinum, arthrosporioides, culmorum, graminearum, gibbosum). Les estérases du mycélium, seul critère enzymatique retenu, permettent de distinguer sans ambiguïté chaque espèce ou variété de Fusarium. Selon les espèces ou les variétés, 6 à 20 bandes enzymatiques sont mises en évidence mais 3 à 4 seulement peuvent servir à leur identification. $\mathrm{F}$ oxysporum, $\mathrm{F}$ solani var coeruleum et $\mathrm{F}$ roseum var arthrosporioides ont des zymogrammes bien distincts; les profils d'estérases de $\mathrm{F}$ roseum var culmorum et de $\mathrm{F}$ roseum var graminearum sont proches tandis que celui de $\mathrm{F}$ roseum var gibbosum forme compactum est plus apparenté à celui de $\mathrm{F}$ roseum var sambucinum qu'aux 2 variétés précédentes. Les résultats obtenus concordent avec les subdivisions définies à partir de la morphologie. En cas d'homogénéité morphologique entre isolats, les isoestérases sont plus stables au niveau de l'espèce ou de la variété que dans le cas des taxons les plus polymorphes. La situation de variation importante est illustrée chez $\mathrm{F}$ roseum var graminearum où les 2 types d'isolats sont mis en évidence ; également chez $\mathrm{F}$ roseum var arthrosporioides, des modifications morphologiques observées s'accompagnent d'altérations isozymiques mais ces fluctuations n'éloignent pas ces variants de cette variété de $\mathrm{F}$ roseum. $\dot{A}$ ce sujet, la relation entre $\mathrm{F}$ roseum var arthrosporioides et $\mathrm{F}$ roseum var avenaceum est discutée. Enfin, cette méthode permet de mettre en évidence des différences entre souches de $\mathrm{F}$ roseum var sambucinum en fonction de leur sensibilité ou résistance au thiabendazole et de leur développement sur mileu de culture.

électrophorèse / isoenzymes / systématique / morphologie 


\section{INTRODUCTION}

Fusarium is one of the most complex of the fungal genera. The current classification is based on morphological characteristics such as pigmentation of colonies on culture media, presence or absence of microconidia, shape of macroconidia, and presence or absence of chlamydospores. This multiplicity of criteria leads to determinative keys that differ according to the authors (Snyder and Toussoun, 1965; Messiaen and Cassini, 1981; Gerlach and Nirenberg, 1982).

Considering the degree of complexity encountered in the genus Fusarium, Booth (1971) suggested using biochemical criteria to better separate the species, varieties, and even formae speciales.

During the 1980s, the techniques for the electrophoresis of proteins and enzymes have proved useful for distinguishing fungal species, especially in genera where morphological criteria are difficult to apply, such as Rhizopus (Seviour et al, 1985), Phytophthora (Hansen et al, 1986; Bielenin et al, 1988), and Peronosclerospora (Micales et al, 1986).

Studies have been successfully carried out using esterases to discriminate between isolates or species of pathogenic agents, such as Fusarium graminearum (Drysdale and Bratt, 1971), Rhizoctonia solani (Matsuyama et al, 1978; Matsuyama, 1983), Phytophthora spp (De Vallavielle and Erselius, 1984), and Ustilago spp (Péros, 1985). Recently, this enzyme system alone was used by Angelstad and Stenersen (1991) in taxonomic studies of the genus Eisenia, by Nobbs et al (1992) to separate 4 species of the cyst nematode Heterodera, by Priestly et al (1992) to identify pathotypes of the eyespot pathogen Pseudocercosporella herpotricoides. Using several enzyme systems some other workers have found esterase to be one of the most useful markers; Roig et al (1990) for comparing isolates of Venturia inaequalis, Somé and Samson (1991) for characterizing phytopathogenic fluorescent Pseudomonas, Simcox et al (1992) for determining races of Cochliobolus carbonum, Lehmann et al (1992) for the identification of the medically important yeast Kluyveromyces marxianus var marxianus.

Early work on the electrophoresis of Fusarium proteins did not result in a consensus as to the value of this method in terms of taxonomic differentiation within this genus. Meyer et al (1964), Hall (1967), Saito et al (1980), and Matsuyama
(1983) have successfully distinguished species and formae speciales of Fusarium. On the other hand, Glynn and Reid (1969) using only the soluble proteins as markers, do not follow the mainstream of opinion that this method could be used as a taxonomic tool.

The works of Reddy and Stahmann (1972) point to the importance of the choice of markers within the Fusarium genus. They used 13 enzyme systems to compare 5 Fusarium species and 6 special forms of $F$ oxysporum, and found that 5 of these enzyme systems (either alone or in combination) could be used as taxonomic criteria.

In Brittany, several species or varieties of $F u$ sarium have been isolated from potato tubers showing dry rot. In order to describe and facilitate detection of these fungi, Tivoli (1988) established an identification guide based on cultural and morphological characters. The present study compares this key with one generated using esterase isozymes as the analytic criteria.

\section{MATERIAL AND METHODS}

\section{Strains}

The strains of Fusarium used in this study came from the Station de Pathologie Végétale, Institut National de la Recherche Agronomique (INRA), Le Rheu, France and were isolated from batches of rotting potatoes produced in Brittany. From these, Fusarium oxysporum, $F$ solani var coeruleum, and $F$ roseum varieties sambucinum, arthrosporioides, culmorum, graminearum, and gibbosum form compactum (according to the classification of Messiaen and Cassini, 1968, 1981) were isolated. Correspondence with basic taxonomy and nomenclature of Wollenweber and Reinking (1935) was made (table I) from the illustrated manual for identification of Fusarium species of Nelson et al (1983).

The strains of each Fusarium species or variety isolated either from a different variety of potato or from a different locality were compared by isolating single conidiospores. Three single spore cultures were recovered for each strains to study intra-isolate variability.

Four isolates of $F$ roseum var graminearum and 1 isolate of $F$ roseum var avenaceum taken from wheat were provided by $L$ Saur from the Station de Génétique et d'Amélioration des Plantes, INRA-Le Rheu. Altogether, 49 single-spore isolates (table II) were studied.

\section{Culture methods}

Six explants $4 \mathrm{~mm}$ in diameter from young malt (Merck, 5391) agar cultures were transferred asepti- 

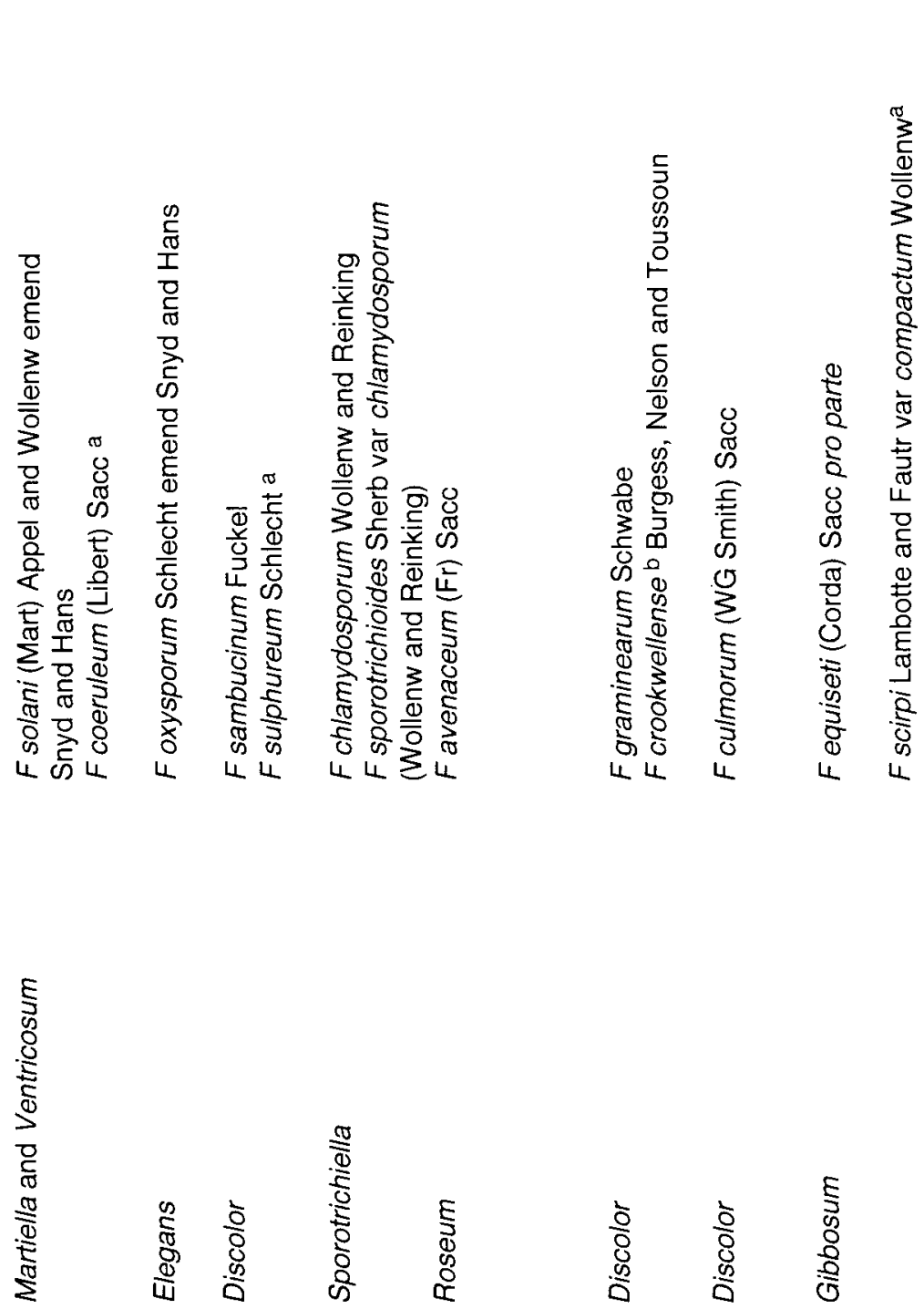

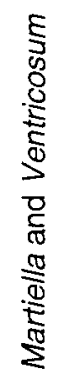

E⿱乛龰
0
0
0
0

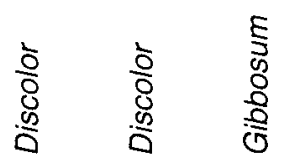

$E$
$\substack{0 \\ 0 \\ 0 \\ 0}$<smiles>C=C=C=C=C=C=S</smiles>

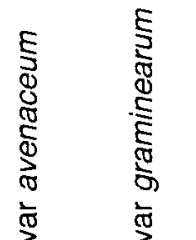

क्षे

के के

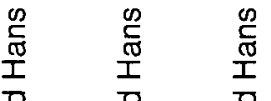

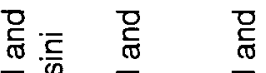

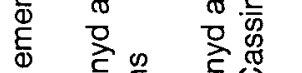

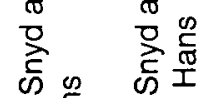

को कू का

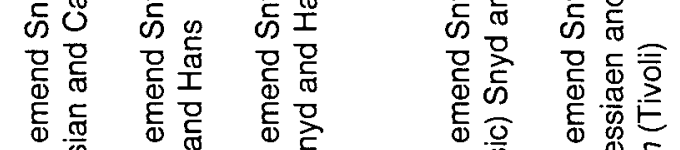

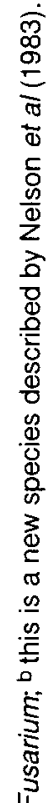




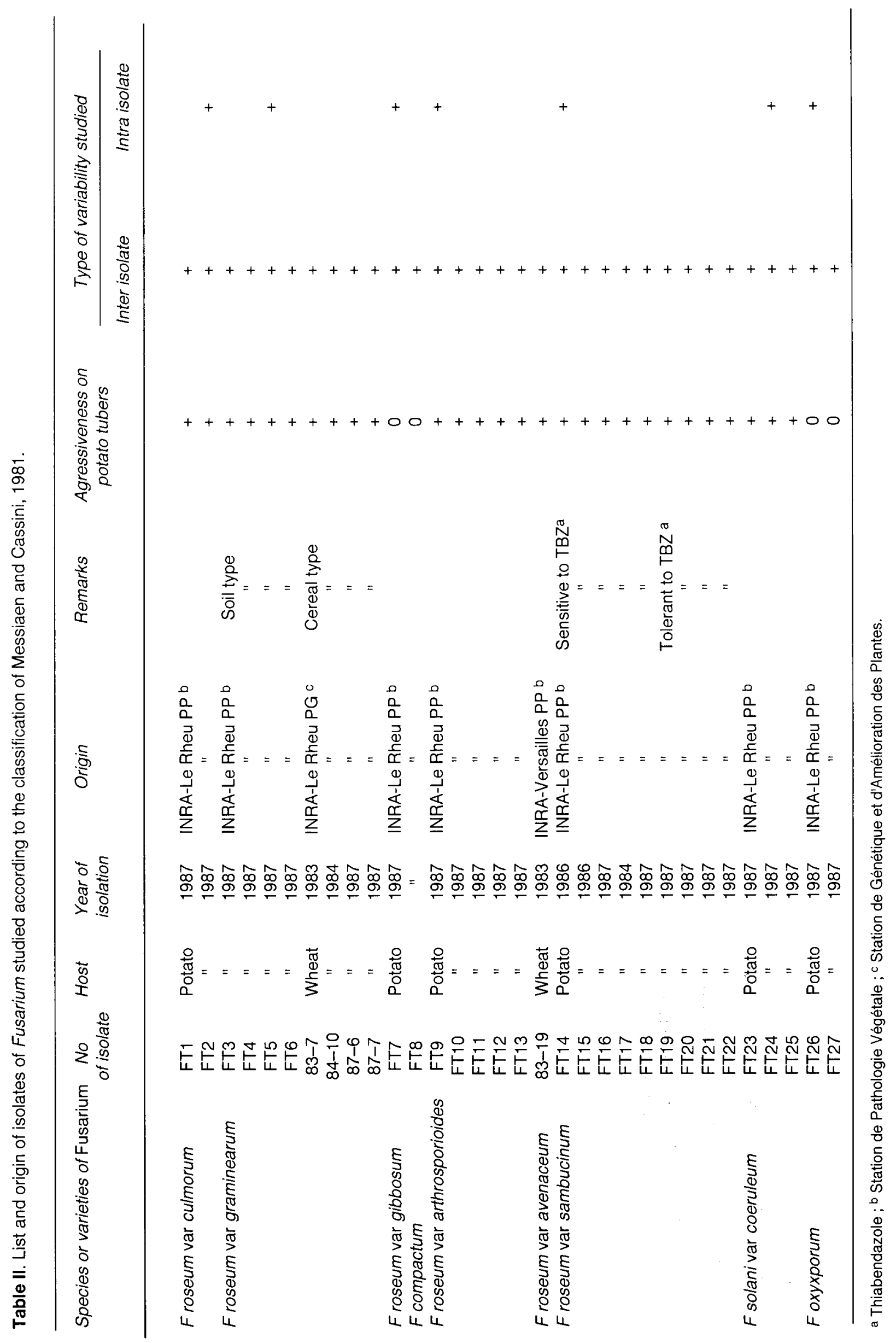


cally into a Roux flask containing $100 \mathrm{ml}$ of the following liquid medium: $10 \mathrm{~g}$ glucose, $3.5 \mathrm{~g} \mathrm{KNO}_{3}, 1.75 \mathrm{~g}$ $\mathrm{KH}_{2} \mathrm{PO}_{4}$, and $0.75 \mathrm{~g} \mathrm{Mg} \mathrm{SO}_{4} .7 \mathrm{H}_{2} \mathrm{O}$ per $1000 \mathrm{ml} \mathrm{H}_{2} \mathrm{O}$ This simple medium used by Bihari (1977) to culture Collectotrichum capsici is also suitable for the growth of Fusarium. The cultures were incubated at $20-24^{\circ} \mathrm{C}$ under 10000 lux white light and a 12-h photoperiod. After $7 \mathrm{~d}$, the culture was filtered through Whatman no 1 filter paper in vacuo to recover the mycelium, rinsed with distilled water, and then lyophilized. The mycelium could then be ground for immediate extraction or stored at $-20^{\circ} \mathrm{C}$ for later use.

\section{Protein extraction}

The method used was adapted from Seviour and Codner (1976): $50 \mathrm{mg}$ Fontainebleau sand and $50 \mathrm{mg}$ insoluble polyvinylpyrrolidone were added to $50 \mathrm{mg}$ lyophilized mycelium in $1 \mathrm{ml}$ extraction buffer kept at $4^{\circ} \mathrm{C}$. This mixture was ground in a mortar (chilled to $-20^{\circ} \mathrm{C}$ ) for $15 \mathrm{~min}$. The extraction buffer was adjusted to $\mathrm{pH} 7$ with $1 \mathrm{~N} \mathrm{HCl}$ containing $10 \mathrm{mM}$ Tris, $1 \mathrm{mM}$ EDTA, 3 $\mathrm{mM}$ 2-mercaptoethanol, and $1 \mathrm{mM}$ cysteine. The supernatant was then centrifuged (at $2^{\circ} \mathrm{C}$ ) at $13000 \mathrm{~g}$ for $10 \mathrm{~min}$ to remove insoluble material, after which glycerol was added to a total of $10 \%$ of the final volume. This protein-rich solution was analyzed immediately or stored at $-20^{\circ} \mathrm{C}$.

\section{Electrophoresis}

One-way vertical electrophoresis on $0.75-\mathrm{mm}$ thick by $70 \times 85 \mathrm{~mm} 9 \%$ polyacrylamide gel was carried out according to Laemmli (1970) in a non-dissociating discontinuous system at $\mathrm{pH} 8.8$ with $20 \mu \mathrm{l}$ of extract solution in each well. Bromophenol blue dissolved in extraction buffer containing $10 \%$ glycerol was deposited in the outer wells to monitor migration. Electrophoresis was carried out in a Bio-Block Mini-Slab apparatus at 150 volts at $4^{\circ} \mathrm{C}$ until the migration front reached the bottom of the gel.

\section{Esterase detection}

Esterases were detected using a modified version of the method of Siciliano and Shaw (1976). $50 \mathrm{mg}$ of Fast Blue RR salts were dissolved in $50 \mathrm{ml}$ of $0.1 \mathrm{M}$ phosphate buffer $(\mathrm{pH} 6)$ at $37^{\circ} \mathrm{C}$. After filtration through Whatman no 1 filter paper, $20 \mathrm{mg} \alpha$-naphthyl acetate and $20 \mathrm{mg} \beta$-naphthyl acetate dissolved in $1 \mathrm{ml}$ acetone were added. After a few seconds of agitation, the gel was incubated in this mixture for $30 \mathrm{~min}$ at $37^{\circ} \mathrm{C}$ in the dark, then rinsed with water and fixed with $10 \%$ acetic acid.

\section{Profile analysis}

The criteria used for assessing the electrophoresis profiles were:

- the relative mobility $\left(R_{\mathrm{f}}\right)$ of the enzyme bands, according to Gottlieb and Hepben (1966):

$$
R_{\mathrm{f}}=b c / b f
$$

were $b c=$ migration distance of a given band; and

$b f=$ migration distance of the leading band; and

- the band intensity, ie how intensely the isoesterase bands take up the staining material.

\section{RESULTS}

\section{General observations}

In the presence of $\alpha$ - and $\beta$-naphthyl acetates as substrates, esterase isozymes stain in 1 of 3 ways:

- a greenish color, indicating reaction with the $\alpha$-substrate;

- a pinkish color, indicating reaction with the $\beta$ substrate;

- an intermediate color between these 2, resulting from simultaneous reaction of the enzyme with both substrates.

Six to 15 enzyme bands were seen for each isolate, depending on the species or variety. Slight intra- or inter-isolate variations did not alter the characteristic profiles of the various Fusarium cultures (figs 1, 2).

The different varieties of $F$ roseum may be distinguished from $F$ solani var coeruleum and Fusarium oxysporum by the presence of a greater number of isoesterases, and the presence of some identically stained enzyme bands that were common to some of them. These similarities include the isoesterases at $R_{\mathrm{f}} 0.29$ in $F$ roseum var culmorum, 0.33 in $F$ roseum var graminearum, and 0.27 in $F$ roseum var arthrosporioides; and the essentially $\beta$-isoesterases of $R_{\mathrm{f}} 0.44$ in $F$ roseum varieties culmorum, graminearum, and sambucinum, and 0.41 in $F$ roseum var gibbosum form compactum. In addition, the enzyme profiles of $F$ roseum var culmorum and $F$ roseum var graminearum are almost identical, as are those of $F$ roseum var gibbosum form compactum and $F$ roseum var sambucinum. 


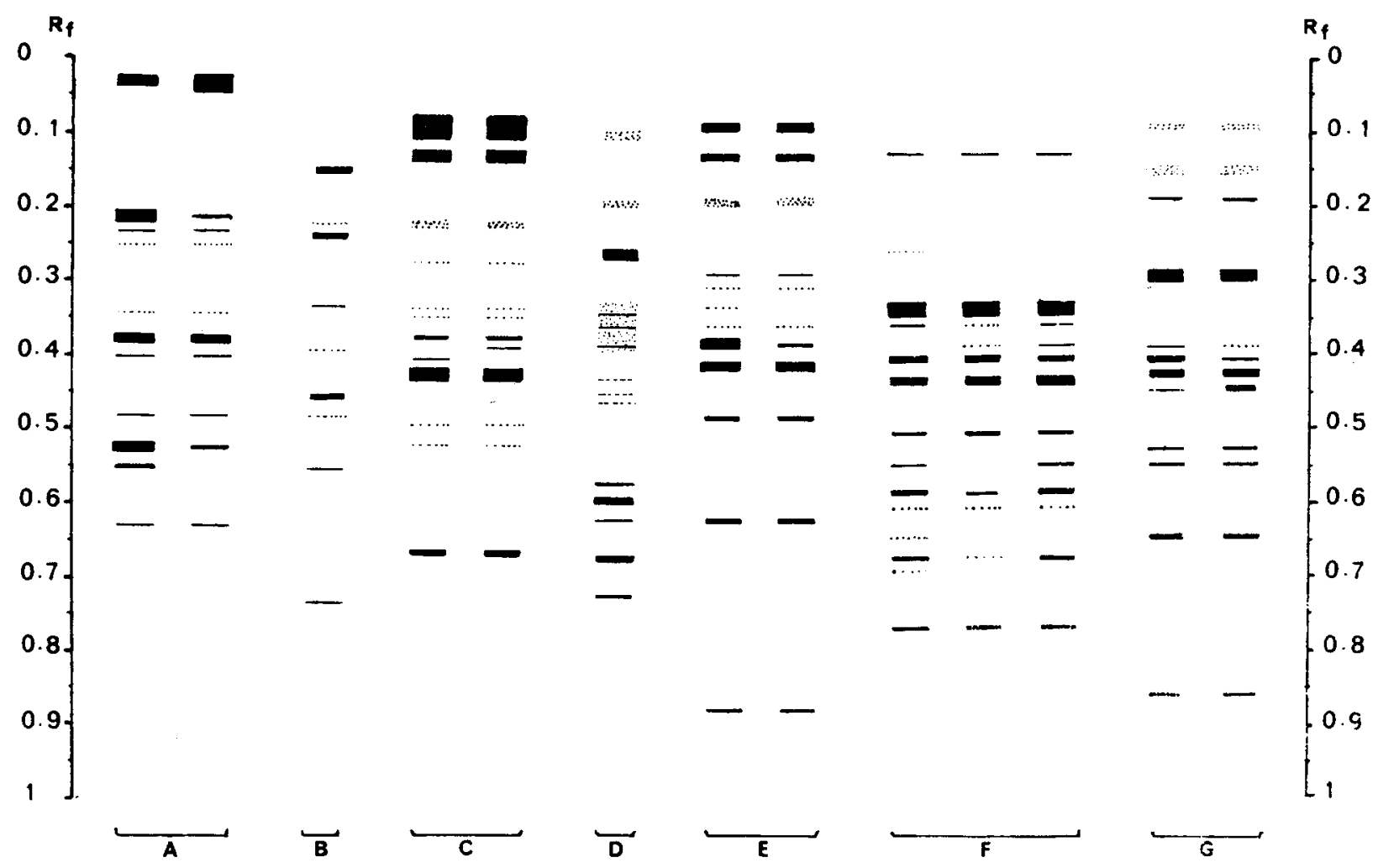

Fig 1. Variability of esterase patterns within a single isolate of each species or variety of Fusarium: $F$ oxysporum (A), $F$ solani var coeruleum $(B), F$ roseum var sambucinum $(C), F$ roseum var arthrosporioides (D), $F$ roseum var gibbosum form compactum $(E)$, $F$ roseum var graminearum (F), F roseum var culmorum $(G)$.

\section{Observations by strain}

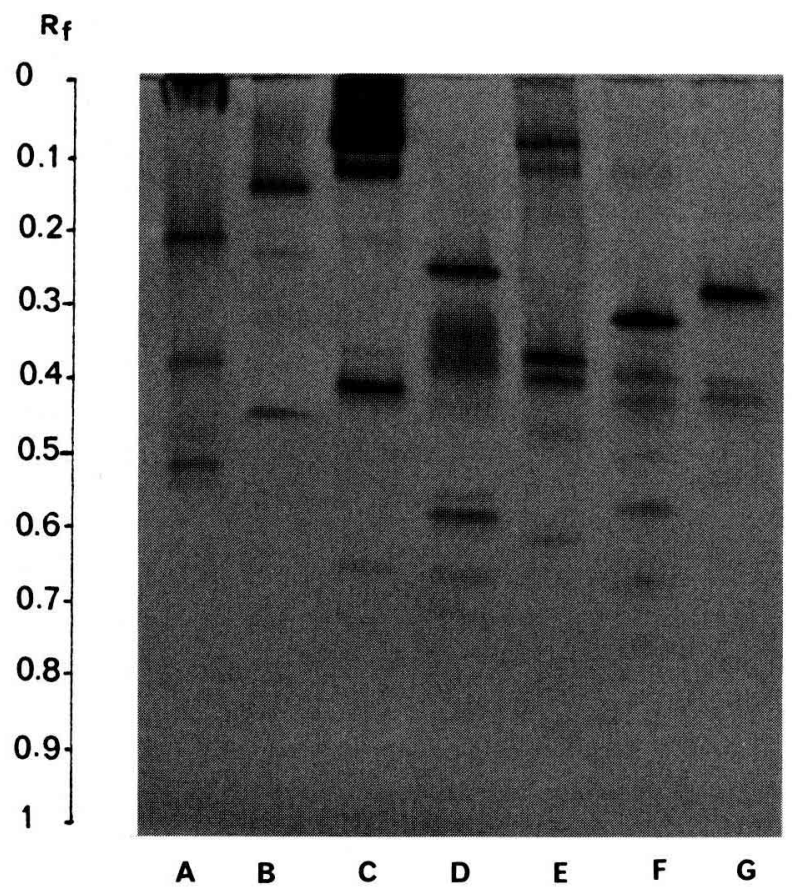

Fig 2. Esterase patterns of different Fusaria from potato: $F$ oxysporum (A), F solani var coeruleum (B), F roseum var sambucinum (C), $F$ roseum var arthrosporioides (D), $F$ roseum var gibbosum form compactum (E), $F$ roseum var graminearum $(\mathrm{F})$, F roseum var culmorum $(\mathrm{G})$.

\section{Intra-isolate variability (fig 1)}

This variability was evaluated by comparing the enzyme profiles of the 3 single-spore cultures from the same isolate for each species or variety of Fusarium.

Generally, the profiles of the 3 single-spore cultures from each species or variety of Fusari$u m$ had the same number of major bands. Single-spore cultures of $F$ solani var coeruleum, $F$ roseum var arthrosporioides showed the same profiles, while for $F$ oxysporum, $F$ roseum var culmorum, $F$ roseum var sambucinum, $F$ roseum var gibbosum form compactum and $F$ roseum var graminearum, variation between the 3 singlespore cultures concerned absence/presence or modification of the intensity of 1 to 3 minor bands.

\section{Inter-isolate variability}

No differences were detected in esterase profiles between isolates of $F$ roseum var sambucinum 
and $F$ roseum var culmorum. In $F$ solani var coeruleum, the only variability among the 4 isolates examined concerned the intensity of the band at $R_{\mathrm{f}} 0.23$.

\section{F oxysporum}

Each of the 2 isolates studied had a different profile: the first had 10 isoesterases, and the second had 6,5 of which were in common to the first. Two $\left(R_{\mathrm{f}} 0.38\right.$ and 0.52$)$ of the 4 major isoesterases were among the missing bands in the second isolate.

\section{F roseum var sambucinum}

Electrophoresis was carried out on 9 strains. Tivoli et al (1986) have shown that some strains of this variety are resistant to thiabendazole in malt agar medium (100 times the dose needed, ie $1 \mathrm{ppm}$, to inhibit growth of susceptible strains). Chosen strains covered both categories. Twelve isozymes were detected, 3 of which were major bands, but there was considerable variability between strains. Isoesterases at $R_{f} 0.36,0.64$, and 0.67 (fig 3) could be present or absent, while those at $R_{\mathrm{f}} 0.08$, $0.12,0.21,0.38$, and 0.39 varied in intensity.

Using these differences in the enzyme profiles, we divided the strains into 4 types:

- Type I: presence of bands at $R_{\mathrm{f}} 0.36$ and 0.64 (in strains FT14, FT15, FT16, and FT17);

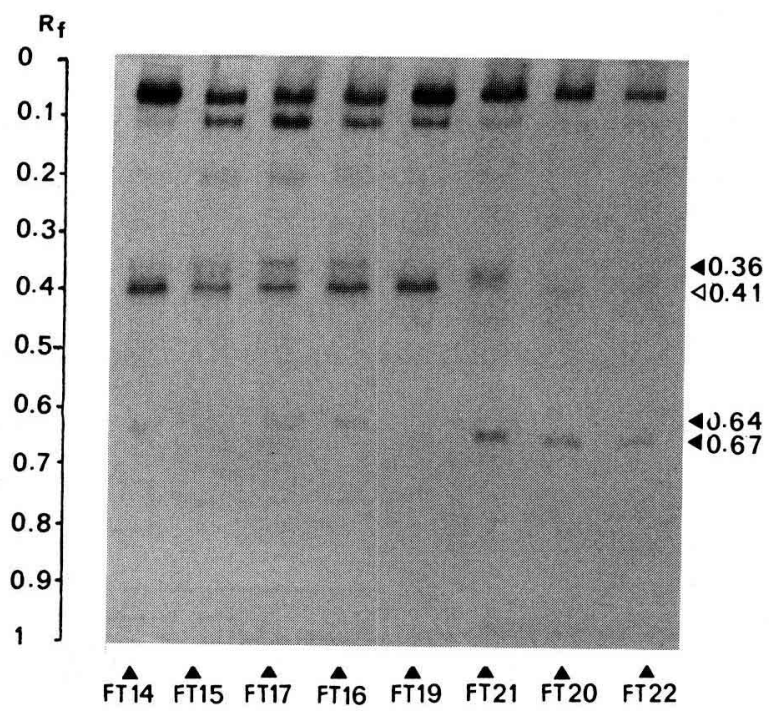

Fig 3. Esterase patterns of strains of $F$ roseum var sambucinum.
- Type II: absence of isoenzyme at 0.36 and presence of one band at 0.67 (in strains FT20, FT21, and DT22);

- Type III: presence of the 2 bands at $R_{\mathrm{f}} 0.36$ and 0.64 but the latter was particularly intense, plus the presence of the 2 other bands at $R_{\mathrm{f}}$ 0.69 and 0.71 (in strain FT18);

- Type IV: absence of the band at $R_{\mathrm{f}} 0.36$ and presence at 0.67 but at low intensity (in strain FT19).

The thiabendazole-sensitive strains (Types I and III) possess the $R_{f} 0.36$ and 0.64 bands but lack the $R_{\mathrm{f}} 0.67$ band, while the resistant strains (Types II and IV) are just the reverse.

\section{F roseum var graminearum}

Inter-isolate variability among the 4 isolates studied (fig 4a) concerned the intensity of the strongest band, and the presence, absence, and/or intensity of the 3 fastest migrating bands.

\section{Observations on the varieties of $F$ roseum}

\section{F roseum var graminearum}

Isolates of this variety taken from the potato may be distinguished morphologically from those originated from wheat by the soil type shape (arched) or their macroconidia, while the

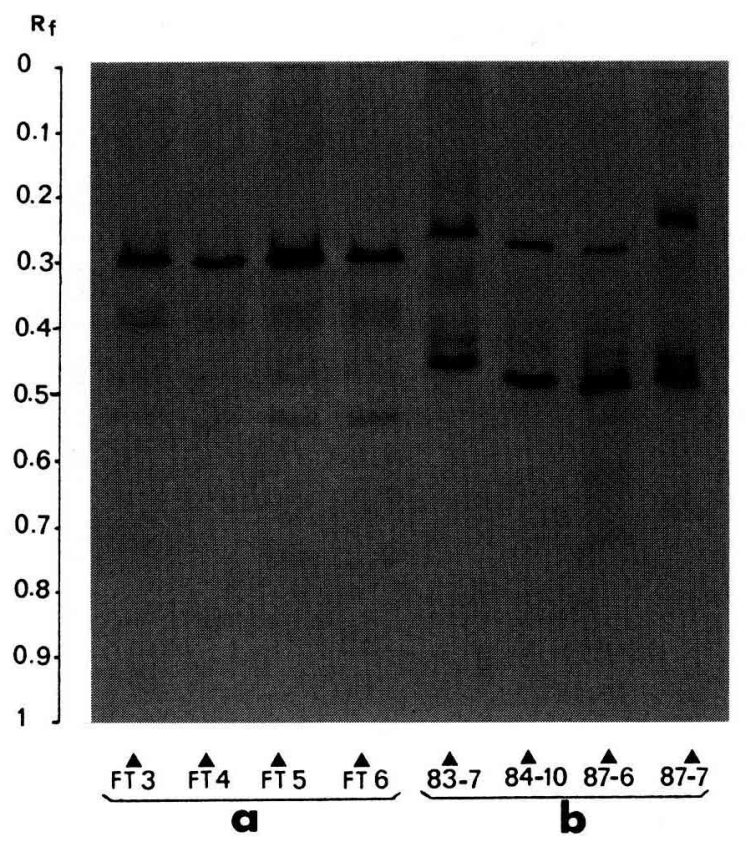

Fig 4. Esterase patterns of $F$ roseum var graminearum: from potato (a), isolates from wheat (b). 
cereal type shape is narrower and hardly curved (Messiaen et al, 1976).

To determine whether the electrophoretic data can be used to partition these isolates into different groups, 4 isolates from potato were compared with 4 isolates from wheat. The zymograms in figure 4 show an overall difference between the potato isolates (a) and the wheat isolates (b). In all, 30 different bands were detected. Figure 5 shows the number of bands that are different, comparing the zymograms two-bytwo. The dendrogram in figure 6 is derived from figure 5 via simple relationships between the isolates, giving 2 groups. The first one, from potato, has few outliers and many bands in common, while the reverse is true for the second group isolated from wheat. However, isolate $87-7$ is markedly different from the 2 groups.

\section{$F$ roseum var arthrosporioides}

While the daughter cultures of single-spore isolates from the other Fusarium species and varieties were morphologically homogeneous, this situation did not always occur with $F$ roseum var arthrosporioides:

- in the most frequent case (FT9, FT12, and FT13), the daughter single-spore isolates were morphologically identical to the parent cultures: that is, they were of the common type described by Tivoli (1988) with a deep carmine red color on contact with the culture medium. A representative zymogram is profile 2 in figure 7; these strains varied by the presence or absence of the

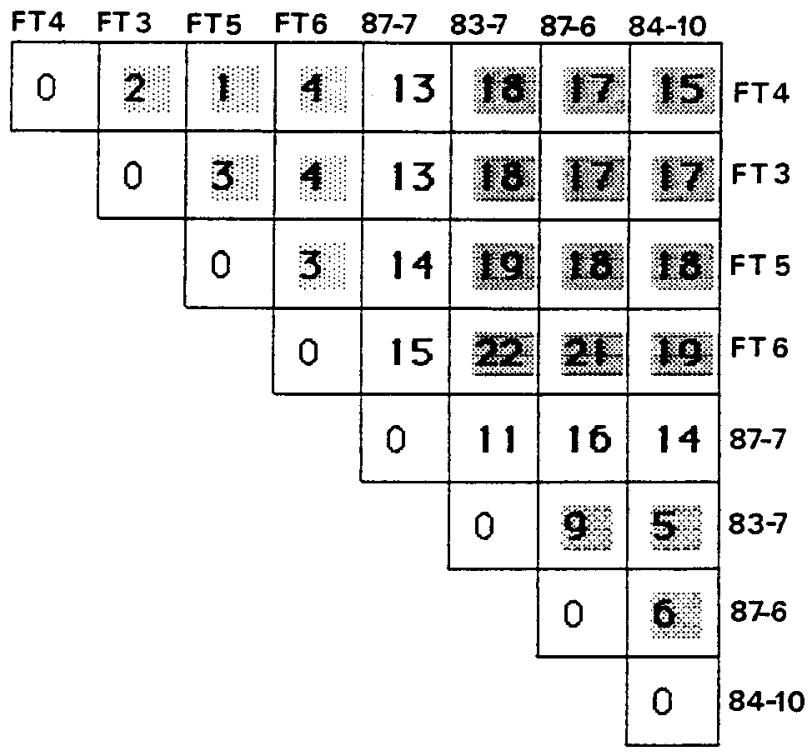

Fig 5. Number of different esterase isozyme bands in each isolate pair of $F$ roseum var graminearum. isozymes at $R_{\mathrm{f}} 0.65$ and 0.75 , and in the intensity of the bands at $R_{\mathrm{f}} 0.10,0.26,0.36$ and 0.39 ;

- in the case of FT10, the daughter single-spore isolates were pink and morphologically identical, but different from the parent cultures. These single-spore cultures are an intermediate between the common carmine red type and the semi-albino type that has lost nearly all of its pigmentation. A zymogram of this isolate is profile 1 in figure 7 , and is marked by the absence of bands at $R_{f}$ $0.13,0.19,0.26,0.36$ and 0.39 , and the exclusive presence of bands at $R_{\mathrm{f}} 0.29,0.51$, and 0.63;

- in the case of FT11, where the 4 daughter single-spore isolates were morphologically different both from each other and from the parent cultures (fig 8) the following was observed: 1 common type daughter isolate; 2 semi-albino type daughter isolates; 1 pionnotal type daughter isolate, characterized by a total lack of aerial mycelium, heavy production of avenaceum-type macroconidia, and an orange-red color. Their respective zymograms are profiles 2, 3, 3', and 4 in figure 7 .

Profile 4 is identical to the esterase zymogram (profile 6 in figure 7) of an isolate of $F$ roseum var avenaceum taken from wheat that also has the pionnotal-type morphology.

Approximately 20 enzyme bands were detected among the isolates of $F$ roseum var arthrosporioides studied. The profiles thus obtained correspond better to the morphological characteristics than to the host origin of the isolates. Profiles 2, 3 and 4 (fig 7) correspond to an analysis of the intra-isolate variability since they are all derived from single-spore cultures of the same original isolate. In the zymograms, the intensity of the bands at $R_{\mathrm{f}} 0.34,0.36$, and 0.39 decreases among the semi-albino types and increases in the pionnotal type, relative to the common type, while the isoenzyme at $R_{\mathrm{f}} 0.26$ which is strong in the common type, decreases in both of the other 2 types.

Thus, there is an intra-isolate variability that does not affect the number of enzyme bands, but may alter the intensity of some. Profiles 4 and 6 (fig 7 ), the 2 pionnotal types from $F$ roseum va-

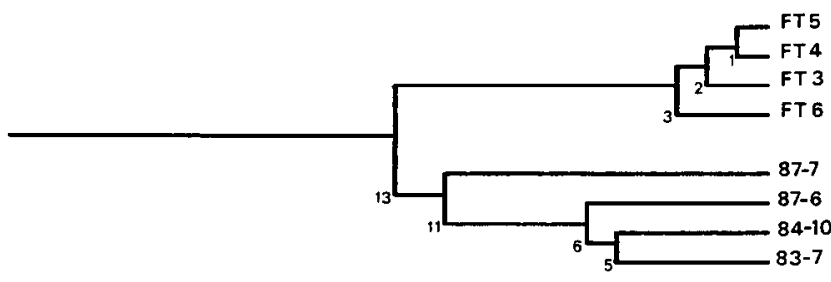

Fig 6. Clustering of the isolates of $F$ roseum var gramine arum by the minimum number of different esterase isozymes in an isolate pair (based on data from figure 5). 
rieties arthrosporioides and avenaceum, respectively, show the same intensity for the bands at $R_{\mathrm{f}} 0.26,0.34,0.36$, and 0.39 .

Based on these observations, we may conclude that intra-isolate variability is greatest among these Fusarium taxa, both in esterase patterns and in morphology.

\section{DISCUSSION}

\section{Congruence of morphological and electrophoretic grouping}

The present study demontrates the congruence between the morphological and electrophoretic

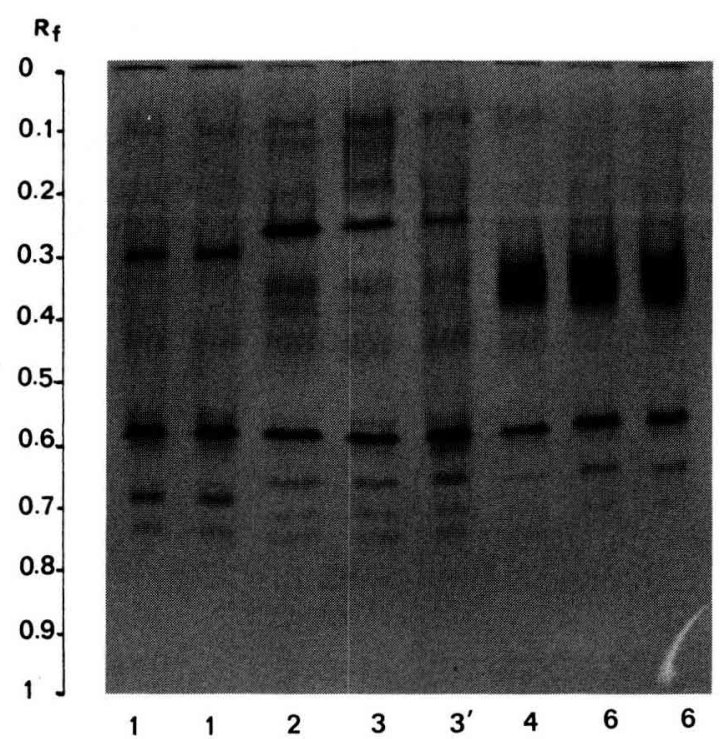

Fig 7. Esterase patterns of isolates of $F$ roseum var arthrosporioides belonging to different morphological groups: (1) isolate FT10, $(2,3,31,4) 4$ single-spore isolates obtained from the isolate FT11 (see table I) and 1 isolate (83-19) of $F$ roseum var avenaceum (6).

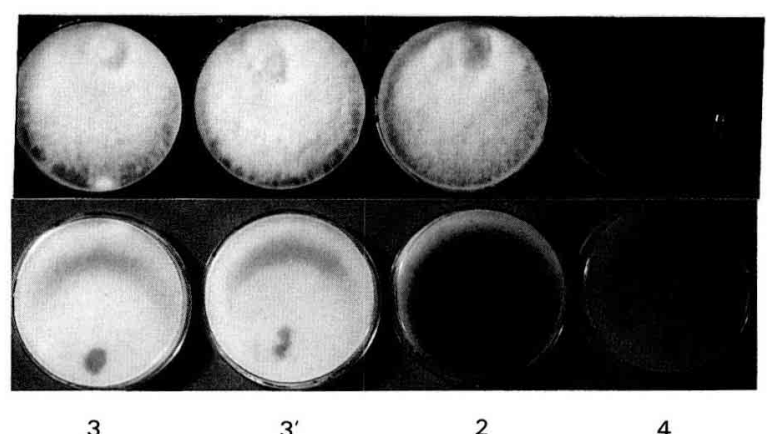

Fig 8. Morphology of 4 single-spore isolates on Tanaka medium (identification medium, Tivoli 1988) obtained from the same isolate of $F$ roseum var arthrosporioides, upper (top), lower (bottom). 2: common type ; 3 and 3': 2 isolates belonging to the semi-albino type; 4 : pionnotal type. characters for the identification of Fusarium spp and varieties found in potato.

The esterases are a good example of an enzyme system that is highly discriminant for species as well as varieties of Fusarium. Assuming that the enzymes detected are coded by different alleles at different genetic loci, then we could conclude that the differences between the profiles reside in the fungal genome. In this case, the groupings detected via the zymograms are very similar to the species or variety subdivisions for Fusarium established by morphology.

The preliminary results from this study are essentially limited to the Fusarium spp found on potato, but it seems likely that this analysis could be extended to isolates of these Fusarium species and varieties that originated from different host plants. This extension would be of particular value in determining the importance of the host-source-dependent morphological variation observed in some varieties by Messiaen and Cassini (1968).

Analysis of variability at the species or variety level shows that there are slight variations in the esterase composition within each group. Nevertheless, strength and constancy of most enzyme bands can serve to group strains of Fusarium with major discriminative bands indicated in figure 9 .

\section{Relationships between $\mathrm{F}$ roseum varieties}

Our studies of $F$ roseum var graminearum showed that the potato isolates and wheat isolates belonged to 2 distinct groups and that there may be additional subgroups within the wheat group. Some isoesterases accentuate this separation: the potato isolates have a major band at $R_{f} 0.31$, with an affinity for the $\beta$ naphthyl acetate substrate. The wheat isolates have 2 major bands; one at $R_{\mathrm{f}} 0.22,0.26$ or 0.28 that are similar in staining to the band at $R_{\mathrm{f}} 0.31$; and the other at $R_{\mathrm{f}} 0.49$ or 0.51 that reacts exclusively with the $\alpha$-naphthyl acetate substrate. These results based on biochemical criteria confirm the existence of at least 2 groups of isolates in $F$ roseum var graminearum, as proposed by Messiaen et al (1976) based on the morphology of their spores and host source. The potato isolates could probably belong to $F$ crookwellense, as described by Burgess et al (1982). These authors used one isolate from France illustrated by 


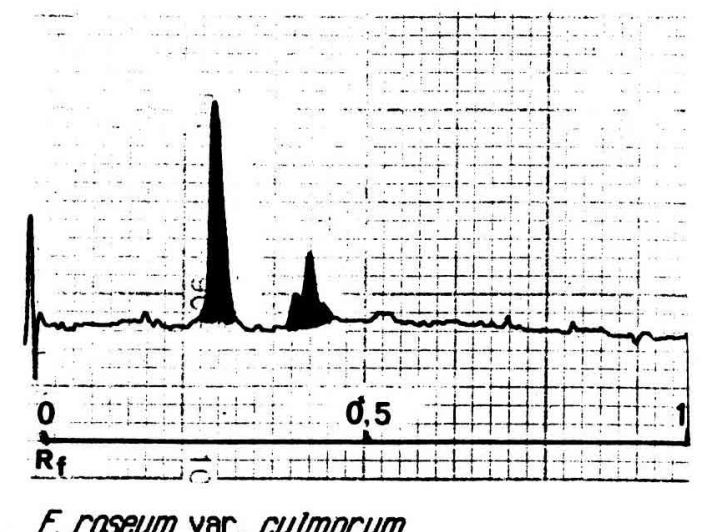

f. raseum ver. culmorum
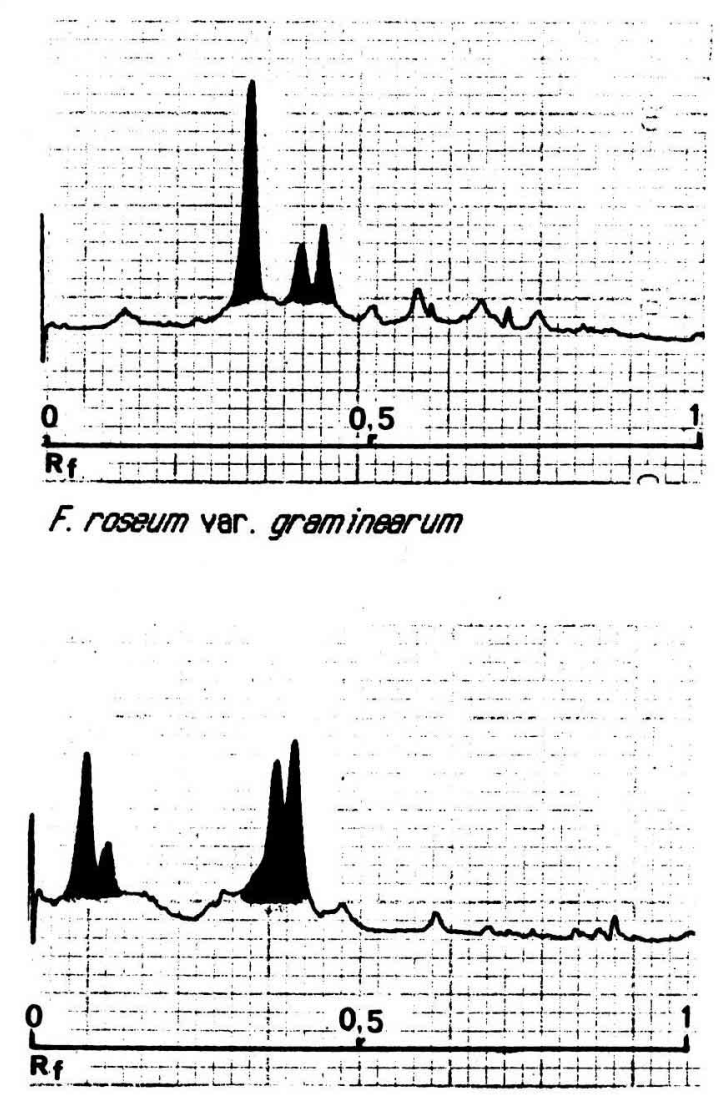

F. roseum var. gibbosum forme compactum

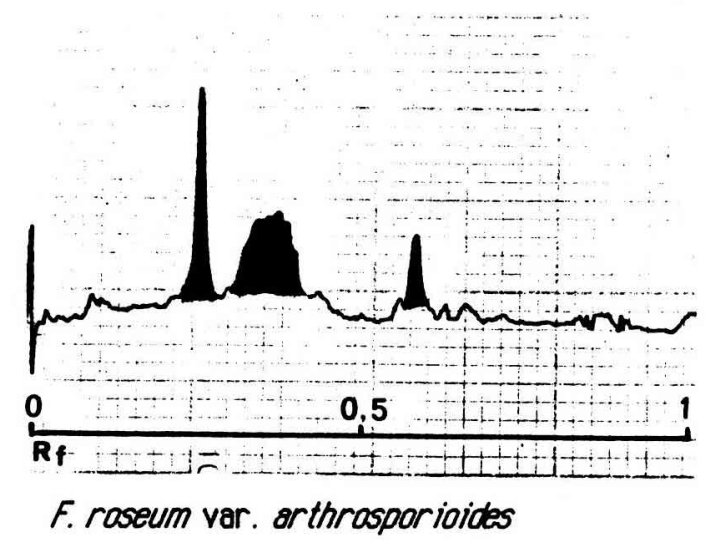

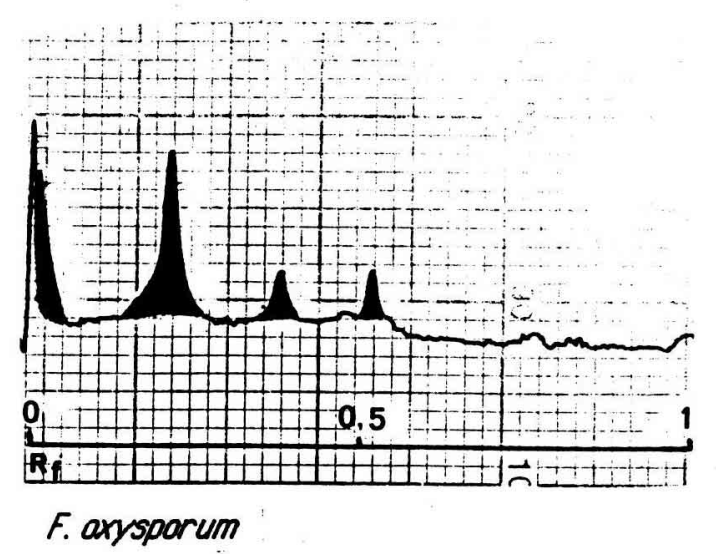

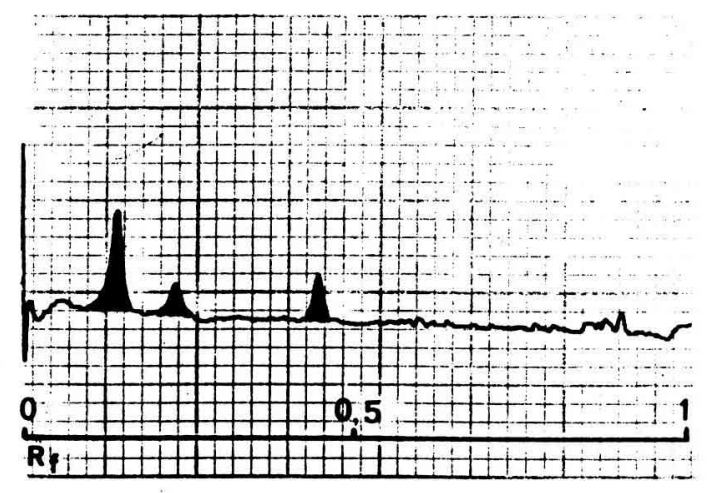

F. solani var. coeruleum

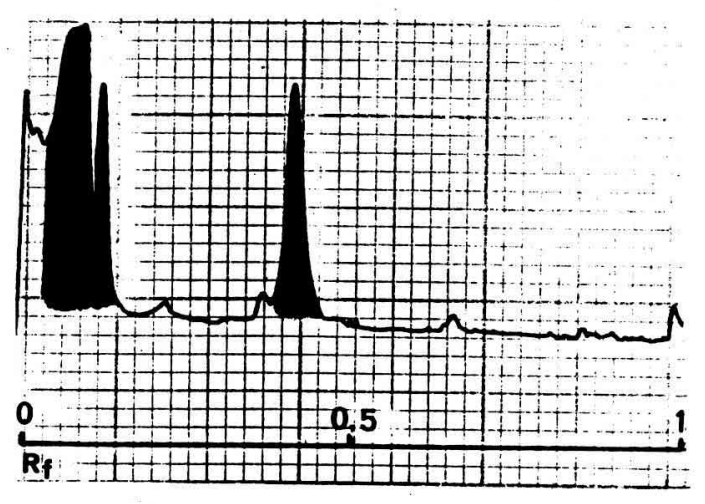

F. roseum var. sambucinum

Fig 9. Densitometer scans of major isoesterases of each species or variety of Fusarium that could be used for identification. 
Messiaen et al (1976) and consider that it is identical to $F$ crookwellense.

The profiles were particularly useful in keeping the various morphological forms of $F$ roseum var arthrosporioides together. On culture medium, the semi-albino variants of this group can easily be confused with $F$ oxysporum, but their enzyme profile is that of $F$ roseum var arthrosporioides. Based on Tivoli's (1988) determination criteria, the pionnotal type might not be classified as Froseum var arthrosporioides: however, the esterase profile of this strain is consistent with its assignment to this variety. In addition to showing this commonality, the refinement of this enzymatic system brings to light variations in intensity of certain isoesterases which correlate with morphological variations.

The limit between $F$ roseum var arthrosporioides and $F$ roseum var avenaceum has been difficult to detect. By studying the morphology and pathogenicity of several isolates of both varieties from different plant hosts, Cormack (1959) concluded that the criteria distinguishing these varieties were not sufficently precise, while Tivoli (1988), also using morphological criteria concluded that $F$ roseum var arthrosporioides and $F$ roseum var avenaceum from potato are the same variety of roseum.

Although the number of samples is limited, we found that $F$ roseum var avenaceum possesses the constant and characteristic bands of $F$ roseum var arthrosporioides. Additionally, the bands at $R_{\mathrm{f}} 0.34,0.36$, and 0.39 were the same for the pionnotal forms of the both varieties. This similarity in their zymograms is supported by their identical morphology and the low aggressiveness of the 2 variants. These 2 varieties could be clonal, and more sensitive techniques will be required to distinguish them.

These pionnotal variants could be considered as degenerate forms of $F$ roseum var arthrosporioides. In addition to enzymatic modifications relative to the common type, a reduction in growth was observed on liquid culture medium, as well as a decrease in aggressiveness, although the symptoms observed in the potato tuber are qualitatively identical to those of the common type. These variants appeared only following singlespore isolation, suggesting that they are at a competitive disadvantage relative to the common type under field conditions. This conclusion is consistent with the proposal of Cormack (1959) who observed that the pionnotal variants had a relatively short lifespan in soil culture, which could explain their relative rarity in soil and other natural environments.

\section{Thiabendazole-resistance in $\mathrm{F}$ roseum var sambucinum and its esterases}

Four enzyme profiles were found for $F$ roseum var sambucinum. These profiles are correlated with the strain's response to thiabendazole, and their development on Bihari's (synthetic) medium. In general, sensitive strains develop well (Type I) on this medium, while resistant strains develop more slowly (Type II). These 2 groups correspond to those already noted by Langerfeld (1986) in $F$ sulphureum. This investigator also observed that thiabendazole-sensitive strains had a normal growth on PDA and Czapek media, while resistant strains were strongly inhibited on the latter medium. Among the strains we analyzed, we noted 2 new groups: Type III (both thiabendazole-sensitive and Bihari's growth inhibited), and Type IV (thiabendazole-resistant with normal growth on Bihari's medium). It is possible that these 2 newly identified types are intermediates between the 2 previously identified types which are more common. On the other hand, our data indicate a difference in nutritional requirements between strains that is independent of fungicide resistance, suggesting that fungicide resistance and nutritional requirements are distinct, even though in most cases they appear to be correlated.

\section{CONCLUSION}

Grouping strains of Fusarium from potato via esterase zymograms is consistent with the grouping based on morphological criteria.

The morphological variability (for example, in $F$ roseum var graminearum and $F$ roseum var arthrosporioides) is correlated with changes in esterase isozyme profiles. Conversely, the absence of morphological variation reflects a certain stability in the esterases at the level of the species or variety.

Since the esterases are easy to detect, this enzymatic system may be incorporated into a key for identifying different Fusarium species and subspecies. Before this step is taken, however, a greater number of isolates should be analyzed to define the limits of isoezyme variability within each group, so that a characteristic 
profile for each species or variety can be established.

Lastly, while the esterases allow various Fusarium taxa to be identified, they are not sufficient for determining familial relationships between them. To help clear up some of the taxonomic problems within the species $F$ roseum, it coud be envisaged, as a complement to the esterases, to use other enzyme systems likely to present greater homology between the isolates of the different varieties, but also certain recent methods such as the technique of sequencing homologous portions of ribosomal RNA, used in the study of phylogeny (Guadet et al, 1989).

\section{ACKNOWLEDGMENTS}

We thank M Le Normand (director of the Chair of Botany and Plant Pathology at the École Nationale Supérieure Agronomique de Rennes (ENSAR)) for providing the electrophoretic materials, D Chicouène (Laboratory of Plant Ecology, University of Rennes I and Laboratory of Botany and Plant Pathology at ENSAR) and $J$ Citharel (Director of the Laboratory of Plant Physiology, University of Rennes I) for helpful suggestions in the preparation of this manuscript, and $J$ Marie (INRA-Versailles) for the translation from French into English.

\section{REFERENCES}

Bielenin A, Jeffers SN, Wilcox WF, Jones AL (1988) Separation by protein electrophoresis of six species of Phytophthora associated with deciduous fruit crops. Phytopathology 78, 1402-1408

Bihari $L$ (1977) The influence of phosphorus sources on growth and sporulation of the isolates of Colletotrichum capsici (Syd) Butler and Bisby. Proc Natl Acad Sci India 47 (B) III, 169-171

Booth C (1971) The Genus Fusarium. CMI Kew, Surrey, UK, pp 237

Burgess LW, Nelson PE, Toussoun TA (1982) Characterization, geographic distribution and ecology of Fusarium crookwellense sp nov. Trans $\mathrm{Br} M y c o l$ Soc 79, 497-505

Cormack MW (1959) Variation in cultural characteristics and pathogenicity of Fusarium avenaceum and F arthrosporioides. Can J Bot 29, 32-45

De Vallavielle C, Erselius LI (1984) Variation in protein profiles of Phytophthora: survey of composite population of three species on citrus. Trans $\mathrm{Br} \mathrm{Mycol}$ Soc 83, 473-479

Drysdale RB, Bratt PM (1971) Electrophoretic patterns of enzymes from isolates of Fusarium graminearum. Trans Br Mycol Soc 57, 172-178
Engelstad F, Stenersen J (1991) Acetylesterase pattern in the earthworm genus Eisenia (Oligochaeta, Lumbricidae): implications for laboratory use and taxonomic status. Soil Biol Biochem 23, 243-247

Gerlach W, Nirenberg H (1982) The Genus Fusarium, A Pictorial Atlas. Paul Parey, Berlin, pp 406

Glynn AN, Reid J (1969) Electrophoretic patterns of soluble fungal proteins and their possible use as criteria in the genus Fusarium. Can J Bot 47, 1823-1831

Gottlieb D, Hepden PM (1966) The electrophoretic movement of proteins from various Streptomyces species as taxonomic criterion. J Gen Microbiol 44, 65-104

Guadet J, Julien J, Lafay JF, Brygoo Y (1989) Phylogeny of some Fusarium species, as determined by large-subunit rRNA sequence comparaison. Mol Biol Evol 6, 227-242

Hall R (1967) Proteins and catalases isoenzymes from Fusarium solani and their taxonomic significance. Aust J Biol Sci 20, 419-428

Hansen EM, Brasier CM, Shaw DS, Hamm PB (1986) The taxonomic structure of Phytophthora megasperma: evidence for emerging biological species groups. Trans Br Mycol Soc 87, 557-573

Laemmli UK (1970) Cleavage of structural proteins during assembly of the head of bacteriophage T4. Nature 227, 680-685

Langerfeld E (1986) Thiabendazol resistenz bei Fusarium sulphureum Nachrichtenbl. Dtsch Pflanzenschutzdienst (Berl) 38, 165-168

Lehmann PF, Khazan U, Wu L-C, Wickes BL, KwonChung KJ (1992) Karyotype and isozyme profiles do not correlate in Kluyveromyces marxianus var marxianus. Mycol Res 96, 637-642

Matsuyama N (1983) The use of zymogram, the measure for delimiting species of Pyricularia and other causal agents of rice diseases. Abstr, 3rd Int Mycol Congr, Tokyo

Matsuyama N, Moromizato Z, Ogoshi A, Wakimoto S (1978) Grouping Rhizoctonia solani Kühn with nonspecific esterase zymogram. Ann Phytopathol Soc Jpn 44, 652-658

Messiaen CM, Belliard-Alonzo L, Barrière $\mathrm{Y}$, De La Tullaye B (1976) Étude qualitative des Fusarium roseum dans des sols des environs de Versailles, sous diverses rotations ou associations végétales. Ann Phytopathol 8, 269-281

Messiaen CM, Cassini R (1968) Recherches sur les fusarioses. IV. La systématique des Fusarium. Ann Epiphyt (Paris) 19, 387-454

Messiaen CM, Cassini R (1981) Taxonomy of Fusarium. In: Fusarium: Diseases, Biology and Taxonomy (PE Nelson, TA Toussoun, RJ Cook, eds) Pennsylvania State Univ Press, 427-445

Meyer JA, Garber ED, Schaeffer SG (1964) Genetics of phytopathogenic fungi. XII. Detection of esterases and phosphatases in culture filtrates of Fusarium oxysporum and $F$ xylarioides by starch-gel electrophoresis. Bot Gaz 125, 298-300

Micales JA, Bonde MR, Peterson GL (1986) Isozyme analysis and aminopeptidase activities within the 
genus Peronosclerospora. Phytopathology 78, 1396-1402

Nelson PE, Toussoun TA, Marasas WFO (1983) Fusarium species. In: An Illustrated Manual for Identification. Pennsylvania State Univ Press, pp 193

Nobbs JM, Ibrahim SK, Rowe J (1992) A morphological and biochemical comparison of the four cyst nematode species, Heterodera elachista, $\mathrm{H}$ oryzicola, $H$ oryzae and $H$ sacchari (Nematoda: Heteroderidae) known to attack rice (Oryza sativa). Fundam App/ Nematol 15, 551-562

Péros JP (1985) Comparaison par électrophorèse d'isolats d'Ustilago scitaminea Syd. Agron Trop (Paris) 40, 72-75

Priestly RA, Dewey FM, Nicholson P, Rezanoor HN (1992) Comparison of isoenzyme and DNA markers for differentiating W-, R-, and C-pathotypes of Pseudocercosporella herpotrichoides. Plant Pathol 41, 591-599

Reddy MN, Stahmann MA (1972) Isozyme patterns of Fusarium species and their significance in taxonomy. Phytopathol Z 74, 115-125

Roig E, Neumann P, Simon JP (1990) Growth and isoenzyme comparison of five isolates of Venturia inaequalis. Phytoprotection 71, 65-71

Saito M, Ichinae M, Tsuruta $O$ (1980) Usefulness of gel electrophoresis comparison of peroxidase for identification of Fusarium species. Trans $\mathrm{Br} \mathrm{Mycol}$ Soc Jpn 21, 229-235

Seviour RJ, Codner RC (1976) Electrophoresis of soluble proteins form light and dark grown culture of Cephalosporium diospyri. Microbios Lett 1, 103-108
Seviour RJ, Pethica LM, Soddell JA (1985) Electrophoresis pattens of sporangiospore proteins of Rhizopus isolates as taxonomic characters. Trans Br Mycol Soc 84, 701-708

Siciliano MJ, Shaw CR (1976) Separation and visualization of enzymes on gels. In: Chromatographic and Electrophorectic Techniques (Smith I, ed) William Heinemann Medical Books Ltd, London, vol 2, 185-209

Simcox KD, Nickrent D, Pedersen WL (1992) Comparison of isozyme polymorphism in races of Cochliobolus carbonum. Phytopathology 82, 621624

Snyder WC, Toussoun TA (1965) Current status of taxonomy in Fusarium species and their perfect stages. Phytopathology 55, 833-837

Somé A, Samson R (1991) Critères protéiques et enzymatiques pour la caractérisation des Pseudomonas fluorescents phytopathogènes. CR Acad Sci (Paris) Ser 3 312, 203-208

Tivoli B (1988) Guide d'identification et distribution écologique des différentes espèces ou variétés de Fusarium rencontrées sur la pomme de terre et dans son environnement. agronomie 8, 211-222

Tivoli B, Deltour A, Molet D, Bedin P, Jouan B (1986) Mise en évidence de souches de $F$ roseum var sambucinum résistantes au thiabendazole, isolées à partir de tubercules de pomme de terre. agronomie 6, 219-224

Wollenweber HW, Reinking OA (1935) Die Fusarien, ihre Beschreibung, Schadwirkung und Bekämpfung. Paul Parey, Berlin, pp 335 